\title{
HINSIDES SEKULARISME OG HVAD SÅ? ${ }^{1}$
}

\author{
Anders Berg-Sørensen
}

\begin{abstract}
ENGLISH ABSTRACT: This article enters the debate on secularism and postsecularism. It questions the conception of secularism as a political doctrine that advocates a strict separation of religion and politics as institutional arrangement and individual reason with reference to ideals of tolerance, impartiality, neutrality, universality, liberty and equality that constitutes a common and independent ground. Instead of conceiving secularism in the singular as it is common in academic and public discourse, the article emphasises secularisms in the plural by pointing at secularisms as political rhetorical strategies within a field of democratic deliberation, negotiation and contestation. This point is illustrated by what could be called a republican secularism and a liberal secularism at the forefront of the recent Danish debate about religion and politics, the Danish church and the state. The article ends by giving priority to democracy over secularism pointing at how the separation of religion and politics limits the democratic processes and practices by exclusion rather than inclusion. Thus, it defends a perspective of pluralism and democracy beyond secularism.
\end{abstract}

DANSK RESUME: Artiklen behandler sekularismens forestilling om adskillelse af religion og politik ud fra én udgave af 'post-sekularismen'. Først skitseres sekularisme som politisk doktrin i ental. Derncest problematiseres denne sekularismeopfattelse ved at vise to former for sekularisme som politiskretoriske strategier $i$ flertal, en republikansk sekularisme og en liberal sekularisme, illustreret med eksempler fra den danske debat om religion og politik, folkekirke og stat. Endelig argumenteres der for at give demokratiet forrang over sekularismen.

KEY WORDS: Religion; Politics; Secularism; Post-secularism; Pluralism; Democracy.

\section{Indledning}

'Post-sekularisme' er blevet en yndet og hyppigt anvendt betegnelse for religionens stigende rolle $\mathrm{i}$ det offentlige og politiske liv, typisk inden for humaniora og samfundsvidenskab (se f.eks. Asad 2003; Berg-Sørensen 2004; Caputo 2001; Connolly 1999, 2005). I det omfang der nu hersker enighed om, hvad det betyder, er det blot den minimale, selvindlysende bestemmelse, at 'vi' har lagt sekularismen, dens adskillelse af

\footnotetext{
${ }^{1}$ Tak til Anna Mischa Sloth Carlsen, Jesper Myrup, Ida Auken Nielsen og Anders Klostergaard Petersen for værdifulde kommentarer. Jeg bærer alene ansvaret for udtalelser og udeladelser.
} 
religion og politik og henvisning af religion til privatsfæren bag 'os' $\mathrm{i}$ en eller anden forstand. Ydermere bliver sekularismens forestilling om et solidt grundlag for politik, som er helt uafhængigt af religion, betvivlet. Det har givet anledning til, at 'postsekularisme' er blevet et slaraffenland for mange idérige hoveder og er blevet tillagt diagnostiske, analytiske og normative betydninger, der spænder fra en nærmest ortodoks genoplivelse af religionens rolle i det offentlige og politiske liv til en fortsættelse af sekularismens projekt $\mathrm{i}$ besindelse på dette projekts begrænsninger. Det er den sidste udgave af 'post-sekularisme', jeg vil forfægte i denne artikel med henvisning til hvad jeg kalder demokratiets forrang over sekularismen.

Inden jeg kommer til præsentationen af min egen udgave af 'post-sekularisme' sidst $i$ artiklen, vil jeg diskutere sekularismens forskellige indhold og former. Da det ikke blot er i den akademiske debat, at spørgsmålet om sekularismens status og religionens rolle i det offentlige og politiske liv har rejst sig, men det i høj grad også er en del af selvforståelsen og -refleksionen i utallige nationale og internationale offentlige og politiske debatter, vil jeg illustrere de teoretiske spor med et eksempel fra den danske debat. Her kommer to former for sekularisme til udtryk: dels hvad jeg kalder en liberal sekularisme, dels en republikansk sekularisme. Det understreger, at sekularismen selv er en omtvistet politisk doktrin, som ikke rummer en entydig betydning, og som har et uafklaret forhold til religionens rolle i det offentlige og politiske liv, hvilket leder frem til den udgave af 'post-sekularisme', jeg kalder demokratiets forrang.

\section{Fra den danske debat}

Nogle af positionerne i den danske debat om forholdet mellem religion og politik kan illustreres med et par udtalelser om social sammenhængskraft, som statsminister og partiformand, Anders Fogh Rasmussen kom med i sin tale ved Venstres Landsmøde d. 27. november 2005. Her understregede Fogh Rasmussen, at sammenhængskraften i det danske samfund skal sikres gennem fælles værdier. For det første refererede Anders Fogh Rasmussen til, hvad der kan kaldes klassiske liberale værdier som kernen i "et vist værdifællesskab.” I Fogh Rasmussens øjne er den liberale kerne borgernes frie og lige rettigheder. Disse opfattes som naturlige og er derfor hævet over hver enkelt borgers egne værdier og tilhørsforhold, religiøst, moralsk, etnisk eller andet. Han nævnte eksempelvis:

Sådan en ting som respekten for det enkelte menneskes liv og frihed. Respekten for at der skal være lige ret for kvinder og mænd, at der er ytringsfrihed i samfundet. Bare for at nævne nogle enkelte grundværdier som man må sige dem må vi stå sammen om, det er en kerne. ${ }^{2}$

For det andet henviste han til den særlige demokratiske tradition, der er blevet udviklet $\mathrm{i}$ Danmark med samtalen som omdrejningspunkt:

\footnotetext{
${ }^{2}$ Se: www.venstre.dk/fileadmin/venstre.dk/files/afrtale_soendag2005.pdf (set 14.12.2005).
} 
Det er den tradition, vi har i Danmark for sådan at snakke os tilrette om tingene. Vi har sådan en pragmatisk indstilling til tingene. ... Det er en del af sammenhængskraften, at vi er gode til at snakke os tilrette om ting. Vi har et samtaledemokrati.

For det tredje peger han på den rolle, som folkekirken har spillet for at skabe fællesskab og sammenhæng i Danmark:

Og det får mig til lige at indskyde en enkelt bemærkning om religionens betydning i det danske samfund. Danmark er jo ikke det vi kalder et sekulært samfund, hvor vi sådan meget præcist har skilt det offentlige liv fra religionen. Og det er vel på den måde en del af sammenhængskraften i det danske samfund, at det danske folk inden for sådan en meget bred og rummelig folkekirkelig ordning har en fælles tro. Ikke at der ikke har været plads til andre trossamfund, det er der jo, det ved vi. Men alligevel, i den der gode ånd, som jeg før var inde på med samtalen hen over bordet og kaffen der har det religiøse liv udfoldet sig i Danmark. Der har været forskellig skarphed i den religiøse overbevisning. Men det har været inden for rammerne af denne samtale og man har kunnet finde fornuftige løsninger på det.

I den forstand knytter Fogh Rasmussen den sammenhængskraft, som folkekirken skaber i det danske samfund i kraft af en fælles tro, an til det, han kalder for det særlige danske 'samtaledemokrati'. Religionens rolle i det offentlige liv indgår som et naturligt element i demokratiet, $i$ hvert fald som det er blevet udviklet $i$ en dansk tradition og bliver opfattet $\mathrm{i}$ en dansk udgave. I den forstand ligger der i Anders Fogh Rasmussens tale nogle tanker om væsentlige værdier hinsides sekularisme. Her tænkes især på den forrang, han tildeler det særlige danske samtaledemokrati, hvor også religionen får en rolle at spille. Det danske demokrati er her det værdifællesskab, han mener, vi skal værne om, for at vi kan stå imod de udfordringer, vi står overfor; udfordringer, som han også tilskriver religionen. Han fortsætter:

Jeg er nødt til at sige lige ud, at den udfordring vi nu ser for sammenhængskraften i det danske samfund, den har jo, i hvert fald fra dem, der udfordrer, sit afsæt i en bestemt religion, nemlig islam. Som vi oplever, i den der udgave, en mere aggressiv religionsudøvelse end vi er vant til i det danske samfund. Jeg vil gerne sige, efter min mening, kan det godt inden for rammerne af det danske samfunds sammenhængskraft, der kan vi godt rumme flere religioner. Men hvis det skal være kombineret med fortsat stærk sammenhængskraft i Danmark, så må enhver religion finde sin plads inden for rammerne af det som jeg vil kalde "det joviale danske samtaledemokrati".

Citaterne fra Fogh Rasmussens tale slår således flere af de strenge an, der kendetegner både den hjemlige og den internationale akademiske og politiske debat om forholdet mellem religion og politik i den vestlige verden og på verdensplan, og således illustreres de teoretiske diskussioner om sekularisme. Spørgsmålet i disse debatter er i kort form, hvordan vi sikrer social sammenhængskraft og fredelig sameksistens mellem samfundets forskellige religioner, trosretninger og livsanskuelser og skaber et grundlag for 
at kunne træffe beslutninger af kollektiv rækkevidde i fælles anliggender. Ofte er der blevet henvist til adskillelsen af religion og politik som forudsætning herfor. Med andre ord bliver sekularismen som politisk doktrin set som forudsætning for social sammenhængskraft og fredelig sameksistens, fordi det fælles grundlag, sekularismen etablerer for politiske beslutninger, bliver opfattet som uafhængigt af religion. Det er imidlertid præcis sekularismens fordring om religiøs uafhængighed, der bliver betvivlet i disse år under betegnelsen 'post-sekularisme': Har vi nogensinde haft en sådan uafhængighed, er den mulig og er den ønskelig? Hvis ikke den er mulig og ønskelig, hvad har vi så at sætte i stedet? Og er henvisningen til historisk indlejrede traditioner og praksisser af religiøs eller politisk karakter, som Anders Fogh Rasmussen anvender, tilstrækkeligt? Skaber en sådan traditionsbevidsthed det fornødne og ønskede grundlag for social sammenhængskraft og fredelig sameksistens i dag?

Umiddelbart rummer Fogh Rasmussens tale en spænding mellem, hvad jeg har kaldt de klassiske liberale værdier og folkekirkens rolle som central faktor i det danske værdifællesskab. På den ene side har vi de klassiske liberale værdier, der består af borgernes lige frihedsrettigheder forstået som religiøst uafhængige rettigheder. Som sådan er de også omdrejningspunkt i sekularismens adskillelse af religion og politik. På den anden side står, hvad Fogh Rasmussen kalder den særlige danske tradition for samtaledemokrati, hvor folkekirken tilskrives en central rolle for skabelsen af fælles værdier og social sammenhængskraft i det danske samfund. Imidlertid skaber det sidste ifølge Fogh Rasmussen "en enighed og et fællesskab om nogle grundprincipper. Blandt andet om ikke at blande politik og religion". ${ }^{3}$ Spørgsmålet er således, om der er en spænding og selvmodsigelse mellem de klassiske liberale værdier som borgernes lige frihedsrettigheder, der er uafhængige af religion, og som nyder statslig beskyttelse, og folkekirkens centrale rolle for skabelsen af fælles værdier og social sammenhængskraft inden for rammerne af et særligt dansk samtaledemokrati? Det er der tilsyneladende ikke, hvis vi spørger statsminister Anders Fogh Rasmussen. Hvordan kan det være? "Danmark er jo ikke det vi kalder et sekulært samfund", men ikke desto mindre lever det ifølge Fogh Rasmussen op til sekularismens fordring om adskillelse af religion og politik.

Hvis vi spurgte forfatterne til en af efterårets meget omdiskuterede debatbøger, Michael Jarlner og Anders Jerichow, så er problemet med håndtering af det stigende antal forskellige religioner, trosretninger og livsanskuelser i det danske samfund netop, at Danmark ikke lever op til sekularismens fordring om adskillelse af religion og politik. Det skyldes, at folkekirken på et både principielt og praktisk plan spiller den centrale rolle for skabelsen af fælles værdier og social sammenhængskraft, som også Anders Fogh Rasmussen peger på i sine taler, men i lyset af en anden positiv vurdering. Jarlner og Jerichow argumenterer derimod i deres bog, Grcenser for Gud, for, at folkekirkens principielle og praktiske særstatus forhindrer, at vi i Danmark kan føre de klassiske liberale værdier som frihed fra statslig indgriben, lige behandling, tolerance og respekt

\footnotetext{
${ }^{3}$ Anders Fogh Rasmussen, “Grundtvig og Kierkegaard - nogle af mine vigtige kilder”, Foredrag, Vartov, 30. november 2005, s. 20. Se: www.sk.ku.dk/amk-afr.pdf (set 19.12.2005).
} 
for forskellighed, demokrati og menneskerettigheder, der er omdrejningspunkt i sekularismen, ud i livet (Jarlner \& Jerichow 2005). Det har ifølge Jarlner og Jerichow negativ betydning for ikke mindst det muslimske mindretal, som udgør den næststørste trosretning i Danmark, og hvis tro er anstødsstenen i Anders Fogh Rasmussens tale. Set gennem Jarlners og Jerichows briller vil det i det konkrete tilfælde være spørgsmålet, om ikke den politisk-retoriske betoning af folkekirkens særlige rolle skaber en alt for skarp grænsedragning mellem en flertals- og en mindretalsbefolkning, der underminerer snarere end funderer den sociale sammenhængskraft i det danske samfund, fordi der bliver lagt tryk på afstanden til mindretalsbefolkningens tro og dermed skabt en yderligere afstand.

Uden at gå videre ind i denne debat her kan vi altså se konturerne af den uenighed, der er om sekularismens og folkekirkens status i dagens Danmark, ikke mindst med henblik på spørgsmålet om at etablere et fælles grundlag for social sammenhængskraft og fredelig sameksistens på et tidspunkt, hvor integrationen af det muslimske mindretal bliver set som en helt central udfordring. Mere præcist kan man spørge, om folkekirkens særstatus er i overensstemmelse med sekularismens fordring om adskillelse af religion og politik, og giver viden og værdier af betydning for, hvordan det danske demokrati fungerer, eller om den snarere er en forhindring for pluralisme og demokrati. Det forudsætter, at vi teoretisk ser nærmere på, hvordan pluralisme og demokrati bliver opfattet og kan opfattes ud fra sekularismens og 'post-sekularismens' perspektiver.

\section{Sekularismer}

I den vestlige verden bliver forholdet mellem religion og politik ofte beskrevet med henvisning til sekularismen som politisk doktrin. Sekularismen og dens vokabularium og tankeformer er de briller, vi bruger til at anskue forholdet mellem religion og politik. Det vil sige, vi sætter grænser mellem religion og politik, og bestræber os på at holde disse adskilt som to af hinanden uafhængige sfærer. Det er eksempelvis hvad Anders Fogh Rasmussen henholdsvis Michael Jarlner og Anders Jerichow hver især bruger som pejlemærker i deres diskussion af folkekirkens rolle i det danske samfund.

I sekularismen som politisk doktrin argumenteres der for en skarp adskillelse af religion og politik både på institutionelt niveau - som institutionelt arrangement - og på individuelt niveau - som individuelt ræsonnement. ${ }^{4}$ Dermed menes, for det første, at vi skal indrette vores offentlige og politiske institutioner på en sådan måde, at de er adskilt fra og uafhængige af religiøse institutioner; for det andet, at autoriseringen og legitimeringen af beslutningskompetence og konkrete beslutninger i de offentlige og politiske institutioner skal være uafhængig af religion, dvs. hvert enkelt individ skal

\footnotetext{
${ }^{4}$ Den kortfattede skitse af elementerne i sekularismen som politisk doktrin, som jeg giver her, trækker primært på Audi’s Religious Commitment and Secular Reason, 2000. Det er der god grund til, ikke blot på grund af Audis klare systematik, men også fordi han tilsyneladende er blevet fast referencepunkt og skydeskive i de internationale politisk teoretiske debatter om sekularisme (se f.eks. Habermas 2005; Laborde 2005; Weithman 2002), og han er samtidig blevet bragt på banen i den danske debat om stat og kirke (se Nielsen 2005).
} 
kunne sætte sig ud over sine eventuelle religiøse overbevisninger og synspunkter i begrundelsen for sine valg og handlinger i de nævnte situationer.

Bag sekularismens adskillelse af religion og politik som institutionelt arrangement og individuelt ræsonnement ligger principper om tolerance, upartiskhed, neutralitet, universalitet, frihed og lighed: staten skal give frihed til, at hvert enkelt individ kan leve det liv, vedkommende ønsker, i gensidig respekt og tolerance for andres livsformer og projekter. Staten må derfor ikke fremme en religion frem for en anden, men skal sikre lige behandling af alle uanset religion, etnicitet, køn eller klasse. Religion og politik skal holdes adskilt på både institutionelt og individuelt niveau for at sikre disse principper. I kraft af adskillelsen af religion og politik med henvisning til de førnævnte principper om tolerance og frihed, upartiskhed og lighed, neutralitet og universalitet har sekularismen etableret et 'objektivt' og rationelt referencepunkt, som i kraft af dets uafhængighed skaber rammerne for social sammenhæng og fredelig sameksistens. Dette er i hvert fald ledemotivet for sekularismen i dag, og det har været det siden sekularismens tidligt moderne formuleringer i det 16. og 17 . århundrede, hvor opgaven var at finde et fælles grundlag for at bilægge stridigheder mellem forskellige religioner, trosretninger og livsanskuelser og indstille forfølgelse af kættere og anderledes troende og tænkende (se Taylor 1998).

Sekularismen søger med andre ord at kunne håndtere pluralisme som samfundsmæssigt vilkår: at give plads til forskellighed og frihed til at leve efter den tro og de værdier, hver især måtte have, samtidig med at dette gøres i fredelig sameksistens med andre ud fra et fælles grundlag, der skaber og sikrer den sociale sammenhængskraft. For at det kan lade sig gøre skal det fælles grundlag ifølge sekularismen være uafhængigt af religion. Det vil sige, sekularismen og dens vokabularium og tankeformer har fokus rettet mod det fælles, uafhængige grundlag og de principper, det består af, og som udgør referencepunktet for indstiftelse og indretning af offentlige og politiske institutioner og for beslutninger i fælles anliggender.

Det sidste knytter sekularismen an til demokrati som det politiske regime, hvor et sådant fælles grundlag findes i form af principper og institutioner. Disse danner rammerne for beslutninger i fælles anliggender af almengyldig karakter. Fra sekularismens perspektiv er det netop i kraft af det fælles grundlags uafhængighed - eller om man vil selvberoende karakter - at beslutningskompetence og konkrete beslutninger i de offentlige og politiske institutioner kan blive autoriseret og legitimeret. Med andre ord har sekularismen som politisk doktrin den demokratiopfattelse, at adskillelsen af religion og politik som institutionelt arrangement og individuelt ræsonnement er en forudsætning for demokrati.

Dette er i kort form elementerne i det perspektiv på forholdet mellem religion og politik, sekularismen danner som politisk doktrin. Det er imidlertid ikke ensbetydende med, at sekularismen er en entydig politisk doktrin. Det giver snarere mening at tale om sekularismer med henvisning til (a) de forskellige institutionelle udtryk, overvejelserne om adskillelse af religion og politik har fået, (b) de forskellige historiske, politiske situationer, de er blevet artikuleret i, (c) de forskellige offentlige og politiske diskurser, 
de indgår i, og (d) de forskellige politiske kulturer og kulturelle selvforståelser, de konstituerer.

Med den baggrundsforståelse, at sekularismen som politisk doktrin skal ses i flertal snarere end i ental, kan man også få blik for, at elementerne i sekularismen bliver tillagt forskellig vægt alt afhængig af kontekst. Det kan illustreres af forskellen mellem amerikansk og fransk sekularisme (se Gunn 2004). Den amerikanske sekularisme betoner eksempelvis hvert enkelt individs religionsfrihed og statens beskyttelse heraf. Samtidig hersker der et mangfoldigt og synligt, offentligt religiøst liv i det amerikanske samfund, og politisk tildeler man religiøse symboler og ceremonier en central, officiel rolle, som skaber en fælles amerikansk identitet og fædrelandsfølelse. Modsat den amerikanske betoner den franske sekularisme statens aktive rolle i skabelsen af en religiøst neutral offentlig sfære som et fælles demokratisk rum, hvor de franske borgere kan blive dannet som selvbestemmende mennesker og ligeværdige medlemmer af den franske republik uafhængigt af religiøst eller etnisk tilhørsforhold, køn eller klasse. I begge tilfælde er skabelsen af social sammenhængskraft som led i et patriotistisk projekt et bærende element.

I det lys bliver det ikke i så høj grad et spørgsmål om pro et contra sekularisme, som det bliver et spørgsmål om, hvilke elementer af sekularismen, der lægges vægt på i de institutionelle arrangementer, offentlige diskurser og politisk kulturelle selvforståelser, hvilke implikationer det har for behandlingen af alle borgere i samfundet både $\mathrm{i}$ princippet og i praksis, og følgelig hvad det betyder for den sociale sammenhængskraft. Det er spørgsmål, der også retter sig mod den danske debat om religion og politik, sekularisme og folkekirke. Jeg vil derfor vende tilbage til, hvad der er blevet opfattet som et klart argument for sekularisme i den danske debat, Jarlners og Jerichows tanker om sekularisme i deres debatbog, Grcenser for Gud.

Jarlner og Jerichow argumenterer for en klar adskillelse af kirke og stat, ikke blot i kraft af en Grundlovsændring, der principielt ophæver folkekirkens særstatus, men også gennem ændringer af institutionelle og kulturelle praksisser, der fra politisk hold privilegerer folkekirken og den evangelisk-lutherske tro, f.eks. civilregistrering, folkekirkens økonomi og ministerielle forankring, folkeskolens kristendomsundervisning, lukkeloven og den officielle kalender inklusiv fri- og helligdage. Jarlner og Jerichow forstår sekularisme på følgende måde:

Sekularisme betyder ikke, at man fraskriver sig retten til at være religiøs. Sekularisme indebærer derimod, at man fastholder religion som et personligt anliggende, som staten skal holde sig udenfor. Sekularisme indebærer, at stater forholder sig religiøst neutrale over for både egne borgere og andre samfund. Religiøs tolerance er et nøgleord (Jarlner \& Jerichow 2005, 62-63).

I den forstand tager Jarlners og Jerichows forsvar for sekularisme i form af en klar adskillelse af kirke og stat udgangspunkt i forestillinger om en religiøst neutral stat som bærende kraft i den offentlige sfære, mens religiøse spørgsmål og forhold er personlige anliggender, der henvises til privatsfæren. På den måde bliver der sikret social 
sammenhængkraft og givet rammer for fredelig sameksistens forskellige religioner, trosretninger og livsanskuelser imellem. I Jarlners og Jerichows tilfælde hviler deres forståelse af sekularisme på tre principper, et princip om frihed med vægt lagt på frihed fra statslig indgriben, men statslig beskyttelse af borgernes frihedsrettigheder, et princip om lighed forstået som både principiel og reel ligebehandling af alle borgere uanset religion, trosretning og livsanskuelse samt et princip om tolerance og respekt for forskellighed. De tre nævnte principper er forankret i menneskerettigheder og demokrati - det sidste som det eneste politiske regime, der kan sikre, at principperne bliver opretholdt og efterlevet. Dermed rummer Jarlners og Jerichows sekularismeforståelse også tanker om en naturlig kobling af sekularisme og demokrati. De skriver:

Demokrati og sekularisme er ikke konkurrerende ideologier, men konkrete redskaber til at lade borgere vælge selv og til at forsikre dem mod at blive påduttet en religiøsitet og dens normer. Sådan hænger religiøs frihed og retten til at blive fri fra religiøs dominans tæt sammen. Temperaturen på menneskerettigheder og retssikkerhed i et samfund vil vise, om borgere har ret til at tro og til at organisere sig i religiøse sammenslutninger. Tilsvarende vil koblingen af stat og religion afsløre, om borgere og religiøse samfund stilles lige - eller om kulturelle eller religiøse dogmer ved lov bruges til at stille borgere forskelligt (Jarlner \& Jerichow 2005, 74).

Det er især sidste sætning i citatet, der viser Jarlner og Jerichows ærinde i den aktuelle danske debat. For dem fører folkekirkens særstatus og de love, hvor folkekirken og den evangelisk-lutherske tro bliver privilegeret, til en både principiel og praktisk forskelsbehandling. Her er det blandt andet folkeskolens kristendomsundervisning, der er anstødsstenen. Den privilegerede rolle som den evangelisk-lutherske tro har fået i det fag, skaber ifølge Jarlner og Jerichow en kobling mellem på den ene side en bestemt trosretning og dens indlejring $\mathrm{i}$ dansk kultur og på den anden side folkeskolens overordnede opgave, at uddanne kommende danske borgere til at kunne begå sig i det danske samfund og demokrati. Lige præcis her sættes der grænser mellem, hvem der er inddraget og kan identificere sig med det danske kulturelle grundlag af evangeliskluthersk tilsnit, og hvem der ikke kan, og det fører forskelsbehandling med sig, mener Jarlner og Jerichow.

Alternativt peger de på, at folkeskolen skal danne de kommende demokratiske borgere ud fra, hvad der er de grundlæggende værdier i et demokratisk samfund og politisk regime. Så opgaven er - snarere end koblingen til den evangelisk-lutherske tro at betone de fælles værdier af menneskeretlig, retsstatslig og demokratisk karakter som uomgængelig viden og erfaringer, som folkeskolen skal kultivere for at sikre, at de kommende borgere ser hinanden som ligeværdige, og at de er ligestillede. I den forstand indeholder Jarlners og Jerichows sekularismeforståelse forestillinger om, ikke blot en religiøst neutral stat, men også en stærk stat, der skaber og bevarer et bestemt politisk fællesskab forankret i menneskerettigheder og demokrati. Det er med andre ord i kraft af en sådan stærk stat, at den sociale sammenhæng bliver skabt og bevaret. I det lys 
ligger Jarlners og Jerichows sekularismeforståelse ikke langt fra hvad man kunne kalde republikansk sekularisme som den franske nævnt ovenfor.

\section{Hinsides sekularismen?}

Ud fra Jarlners og Jerichows sekularismeforståelse og kritiske indstilling til folkekirkens særstatus er det spørgsmålet, hvordan vi skal forstå Anders Fogh Rasmussens påstand om, at folkekirkens rolle for skabelsen af social sammenhængskraft i Danmark er i overensstemmelse med ønsket om at holde religion og politik adskilt. Ligesom Jarlner og Jerichow ønsker han en adskillelse af religion og politik, og han opfatter oven i købet religion som et personligt anliggende, der er henvist til privatsfæren. Men ikke desto mindre spiller folkekirken en central rolle i det offentlige rum for skabelsen af det værdifællesskab, der sikrer den sociale sammenhængskraft. Når der ifølge Fogh Rasmussen på dette punkt er tale om en overensstemmelse snarere end en selvmodsigelse må det være, fordi sondringen mellem religion og politik er del af det evangelisk-lutherske tankegods og dermed del af folkekirkens bekendelsesgrundlag.

Fogh Rasmussen udfolder ikke selv denne pointe yderligere, end det fremgår af citatet $\mathrm{i}$ indledningen, men det har hans partifælle, folketingsmedlem Birthe Rønn Hornbech gjort, bl.a. i kritik af Jarlners og Jerichows debatbog, Groenser for Gud. Birthe Rønn Hornbech skriver:

Forfatterne har ikke forstået, at de protestantiske lande allerede er de frieste i verden, fordi der netop i den evangelisk-lutherske kirke skelnes mellem lov og evangelium, det verdslige og det kirkelige regimente, og at trosfriheden og åndskampen også i det offentlige rum er en naturlig konsekvens af denne skelnen./Bogen er en lang krænkelse af åndsfriheden, og forfatterne vil ikke forstå, at netop folkekirken dæmmer op for, at staten bliver religiøs og kirken politisk. ${ }^{5}$

Det selv samme synspunkt har Birthe Rønn Hornbech også forfægtet i en mere generelt anlagt artikel, hvor hun med henvisning til netop denne skelnen mellem lov og evangelium understreger, at folkekirkens præster har til opgave

at holde den verdslige øvrighed fast på den evangelisk-lutherske skelnen mellem lov og evangelium for dermed at fastholde øvrigheden på dets opgaver om at opretholde ro og orden i samfundet uden at frelse og dermed tyrannisere sjælene (Hornbech 2005, 16).

Det interessante i de uddybende bemærkninger fra Birthe Rønn Hornbechs hånd, som jeg her har tilføjet til hendes partiformand, statsminister Anders Fogh Rasmussens tale ved Venstres landsmøde, er, at de viser, hvordan henvisningen til folkekirkens rolle for skabelsen af social sammenhængskraft i Danmark søges indpasset i et gængs sekularistisk vokabularium og tankesæt, hvor adskillelsen af religion og politik er omdrejningspunkt. Med andre ord bliver argumentet, at det er $i$ kraft af folkekirken og dens

${ }^{5}$ Kristeligt Dagblad, 21. oktober 2005. 
evangelisk-lutherske tro, at det er muligt at holde religion og politik adskilt, hvad sekularismen fordrer; det er ikke, at folkekirkens særstatus er $i$ modstrid med en adskillelse af religion og politik, som kritikere som Jarlner og Jerichow argumenterer for. Endvidere rummer Birthe Rønn Hornbechs udfald mod Jarlner og Jerichow en slet skjult afstandtagen fra deres forestilling om en stærk fællesskabsdannende og bevarende stat formuleret ud fra et individuelt frihedsperspektiv.

Med de to valgte punktnedslag i den danske debat kan vi se konturerne af to forskellige sekularismeforståelser: (1) en, der lægger vægt på, at adskillelsen af religion og politik bliver sikret i kraft af en stærk stat, der skaber et fællesskab ved at kultivere menneskerettigheder og demokrati som et fælles værdigrundlag, hvad jeg tidligere har kaldt republikansk sekularisme. $\operatorname{Og}(2)$ en, der ser adskillelsen af religion og politik som en del af statens opgave med at beskytte den enkeltes frihed, bl.a. religionsfrihed, hvis udøvelse er henvist til privatsfæren, samtidig med folkekirken og den evangelisklutherske tro tilskrives muligheden for i det hele taget at kunne foretage den sondring, hvad jeg vil kalde liberal sekularisme.

Det understreges ydermere, hvis vi ser på de opgaver, Birthe Rønn Hornbech tildeler henholdsvis "øvrigheden" - "at opretholde ro og orden i samfundet" - og folkekirken "at fastholde sondringen mellem lov og evangelium med det sidste for øje" samt "at frelse ... sjælene.” Det er næsten som at læse en af liberalismens fædre, John Lockes (1632-1704) Et brev om tolerance, udgivet anonymt i 1689. Locke ser det som øvrighedens opgave "at beskytte og fremme borgerlige goder" som "livet, friheden, et helt og sundt legeme fri for smerter, samt ydre besiddelser, som jordegods, penge, bohave etc.", mens kirkens opgave er "omsorgen for sjælene" og "sjælenes frelse" (Locke 2003, 6063).

Med henvisningen til Locke er vi tilbage ved de klassiske liberale værdier, som Anders Fogh Rasmussen nævnte som et af de tre bærende elementer i et dansk værdifællesskab, menneskets naturlige, ukrænkelige og umistelige lige frihedsrettigheder, som er uafhængige af religion, og som det er statens opgave at beskytte og fremme. Ydermere udkrystalliserer Lockes tolerancebegreb sammenfaldet mellem protestantisme og liberalisme i form af det fokus, der er rettet mod (a) hvert enkelt individ som omdrejningspunkt $i$ både religiøse og politiske anliggender, (b) religion som hvert enkelt individs eget Gudsforhold og sjælefrelse, (c) hvert enkelt individs samvittighed og absolutte valgfrihed religiøst såvel som politisk, og (d) beskyttelsen af hvert enkelt individ i kraft af dets lige frihedsrettigheder, som opfattes som naturlige, ukrænkelige og umistelige. I den særlige form, som netop er blevet refereret, forudsætter Lockes tolerancebegreb sekularismens adskillelse af kirke og stat, men det er samtidig en adskillelse, der er forankret i en bestemt, protestantisk opfattelse af religiøse mennesker og trossamfund. Det sidste markerer rækkevidden af Lockes tolerancebegreb, at der er nogle bestemte, religiøst tonede forudsætninger for, hvem der politisk kan tolereres, og hvem der ikke er omfattet af toleranceprincippet; især ateister er udelukket, men det er ligeledes omtvistet, om andre trosretninger og religioner, der 
prioriterer ikke-individuelle og kollektive aspekter er omfattet af toleranceprincippet (se f.eks. Schwartzman 2005; Spinner-Halev 2005; Waldron 2002).

Tilsvarende Lockes protestantisk inspirerede og tonede liberalisme tilskriver Anders Fogh Rasmussen hvert enkelt individs samvittighed en overordnet rolle for social sammenhængskraft uafhængigt af religion. Han siger:

Måske er samvittigheden netop det evige i mennesket. Måske er samvittigheden det objektive etiske normsæt, som er instansen over mennesket. I så fald mener jeg godt, at man kan argumentere for eksistensen af et objektivt etisk normsæt uden at tage et religiøst udgangspunkt. For samvittighed, tror jeg, er noget mennesket iboende. ${ }^{6}$

Spørgsmålet er altså, om der med parallellen til Lockes protestantiske og liberale tolerancebegreb også er fare for en tilsvarende religiøst forankret politisk bestemt udelukkelse i, hvad man på paradoksal vis kunne kalde Birthe Rønn Hornbechs og Anders Fogh Rasmussens liberale sekularisme. I hvert fald underspiller de med deres betoning af folkekirken og den evangelisk-lutherske tro som ramme for individuel frihed og social sammenhængskraft vigtigheden af hvert enkelt individs ligeværdighed og lige behandling uanset religion, trosretning og livsanskuelse. De er tilsyneladende med henvisningen til et 'objektivt' element i deres position blinde over for, at deres synspunkter er udtryk for en religiøst funderet politisk handling, der fastholder billedet af en prioriteret flertalsbefolkning, mens mindretalsbefolkningen ikke direkte tildeles en rolle, men fastholdes som mindretal. Der er således også en fare for, at den type politisk retorik snarere svækker end styrker den sociale sammenhængskraft.

\section{Demokratiets forrang}

Jeg har indtil videre vist, at både en såkaldt republikansk sekularisme og en såkaldt liberal sekularisme taler for en adskillelse af religion og politik som en forudsætning for demokrati, selvom forholdet mellem religion og politik stadig ikke står krystalklart i de to nævnte positioner, som jeg har forsøgt at læse ud af den danske debat. Til trods for uenigheder om folkekirkens rolle i det offentlige rum henviser begge positioner til en adskillelse af religion og politik ud fra en opfattelse af religion som et personligt anliggende, der hører privatsfæren til, mens politik drejer sig om fælles anliggender, der drøftes i den offentlige sfære med forestillinger om rationel kommunikation og naturlige, ukrænkelige og umistelige rettigheder uafhængige af religion som fælles 'objektivt' grundlag og referencepunkt.

Det er imidlertid spørgsmålet, om sekularisme i form af en adskillelse af religion og politik og en efterfølgende sondring mellem privat og offentligt er en nødvendig forudsætning for demokrati, som påstået; det er med andre ord spørgsmålet, om det er nødvendigt, at sekularismen har forrang for demokratiet. Kan demokratiet ikke stå alene? Jeg vil afslutningsvis argumentere for det sidste, at demokratiet har forrang. Det

\footnotetext{
${ }^{6}$ Anders Fogh Rasmussen, “Grundtvig og Kierkegaard - nogle af mine vigtige kilder”, Foredrag, Vartov, 30. november 2005, s. 17. Se: www.sk.ku.dk/amk-afr.pdf (set 19.12.2005).
} 
er i den forstand, jeg mener, at betegnelsen 'post-sekularisme' giver mening som en fortsættelse af sekularismens projekt, hvad angår idéerne om frihed til at leve det liv, man ønsker at leve, i respekt og anerkendelse af hinanden og ligeværdighed og ligebehandling uanset religion, trosretning og livsanskuelse, samtidig med at det er en besindelse på sekularismens egne begrænsninger og grænsesætninger uden henvisning til et fælles 'objektivt' grundlag. Forudsætningen for, at disse idéer om frihed og lighed kan føres ud i livet er ikke sekularismens adskillelse af religion og politik i sig selv, for selv bestræbelser på at adskille religion og politik fører til krænkelser af disse idéer i praksis, hvad de to former for sekularisme i den danske politiske retorik viser; det er snarere en opgave for demokratiets selvskabte og selvberoende processer, praksisser og institutioner at lade grænsedragningen mellem religion og politik stå til stadig forhandling og således besinde sig på demokratiets åbne karakter (se f.eks. Keenan 2003).

Første skridt i dette argument for en form for 'post-sekularisme' som en videreførelse af sekularismens projekt er, at sekularisme ikke forstås som en entydig politisk doktrin, men forskellige politisk-retoriske strategier, der tilskriver adskillelsen af religion og politik en afgørende rolle i et moderne demokratisk samfund for social sammenhængskraft og fredelig sameksistens. Dermed er 'sekularismerne' blot indlejret i forskellige offentlige debatter og politiske kampe; de står ikke udenfor som naturlige og almengyldige referencepunkter hævet over tid og sted, hvad de ellers i egen selvforståelse søger at fremskrive og overbevise om. De blander, som vi har set, elementerne i en sekularisme på forskellig måde med forskellig prioritering og med forskellige politiske og praktiske implikationer til følge. Det kan f.eks. være den liberale sekularismes adskillelse af religion og politik i kraft af en særligt prioriteret religiøs institution, folkekirken, og en særligt prioriteret trosretning, den evangelisk-lutherske tro, som væsentlige elementer i hvad der skaber individuel frihed og social sammenhængskraft, men med negative implikationer for de mindretal, der ikke tilhører folkekirken, fordi de ikke bliver behandlet lige.

Næste skridt er anerkendelsen af, at de politisk-retoriske strategier i de offentlige debatter og politiske kampe ikke har anden gyldighed og autoritet end den de får i de demokratiske sammenhænge, de indgår i. De er hverken mere eller mindre, end hvad de fremstår som heri. Det er den forrang, jeg tildeler demokratiet som selvskabte og selvberoende processer, praksisser og institutioner, hvor borgernes karaktertræk og handlekraft bliver kultiveret. Det betyder også, at historisk indlejrede traditioner og praksisser af religiøs og politisk karakter ikke har autoritet i sig selv, f.eks. folkekirken og den evangelisk-lutherske tros rolle i det danske samfund og offentlige rum, men blot er en stemme blandt andre og stadig er til debat i lyset af samfundets forandringer og befolkningens forskellige perspektiver. Det er således mit ærinde at pege på demokratiets iboende åbne karakter på både institutionelt og individuelt niveau. I stedet for at lukke disse demokratiske processer, praksisser og institutioner med henvisning til en adskillelse af religion og politik, som alligevel ikke synes opretholdt og mulig at opretholde, er det for mig at se i overensstemmelse med sekularismens projekt at lade så 
mange stemmer som muligt komme til orde, religiøse såvel som ikke-religiøse, og opfatte dem som ligeværdige og behandle dem lige. Det giver de bedst mulige rammer for at så mange mennesker som muligt kan blomstre i overensstemmelse med egne værdier og visioner.

Det er mit spinkle håb, at dette perspektiv kan være med til at åbne øjnene for 'sekularismernes' eksklusion af mindretal og modsat vise mulighederne for inklusion i kraft af anerkendelse af forskellige identitetsmarkører, så mindretallene også kan føle sig som ligeværdige. En sådan åbning af det offentlige rum for religiøse ytringer, synspunkter og symboler er ikke ensbetydende med et knæfald for religion og religiøse autoriteter; tværtimod giver det større muligheder for kritisk engagement i demokratiets processer og praksisser for hvert enkelt menneske, hvis alle har en ligeværdig stemme og bliver mødt på egne præmisser uden krav om frafiltrering af bestemte identitetsmarkører i det offentlige og politiske liv, i 'sekularismernes' tilfælde frafiltrering af religiøse (se Connolly 1999, 2005). Det kan være med til at holde demokratiet i live samtidig med visheden om dets skrøbelighed. I det lys har mit ærinde i artiklen været at vise mulighederne for pluralisme og demokrati hinsides sekularismens adskillelse af religion og politik. Det retter fokus mod de løbende konkrete forhandlinger om forholdet mellem religion og politik i de demokratiske processer og praksisser og rejser spørgsmål, som i kraft af demokratiets åbne karakter ikke kan besvares en gang for alle.

\section{Litteratur}

ASAD, TALAL

2003 Formations of the Secular. Christianity, Islam, Modernity, Stanford University Press, Stanford.

AUDI, ROBERT

2000 Religious Commitment and Secular Reason, Cambridge University Press, Cambridge.

BERG-SøRENSEN, ANDERS

2004 Paradiso-Diaspora. Reframing the Question of Religion in Politics, Ph.d.-afhandling, Institut for Statskundskab, Københavns Universitet, København.

CAPUTO, JOHN D.

2001 On Religion, Routledge, London.

CONNOLly, William E.

1999 Why I Am Not a Secularist, University of Minnesota Press, Minneapolis.

2005 Pluralism, Duke University Press, Durham.

GunN, T. JEREMY

2004 "Religious Freedom and Laïcité: A Comparison of the United States and France", Brigham Young University Law Review, No. 2, 419-506.

HABERMAS, JÜRGEN

2005 Zwischen Naturalismus und Religion. Philosophische Aufsätze, Suhrkamp Verlag, Frankfurt am Main.

HORNBECH, BIRTHE RøNN

2005 “Gud og politik”, in: Jørgen Carlsen, Hans Kelstrup, Henning Nielsen \& Henrik WighPoulsen, eds., Gud \& Politik. Vartovbogen 2005/6, Forlaget Vartov, København, 9-19. 
JARLNER, MICHAEL \& ANDERS JERICHOW

2005 Groenser for Gud-giv det verdslige samfund en chance, Gyldendal, København.

KEENAN, Alan

2003 Democracy in Question. Democratic Openness in a Time of Political Closure, Stanford University Press, Stanford.

LABORDE, CÉCILE

2005 "Secular Philosophy and Muslim Headscarves in Schools", The Journal of Political Philosophy, Vol. 13, No. 3, 305-29.

LOCKE, JOHN

2003 Et brev om tolerance, oversættelse, indledning og noter, Mogens Chrom Jacobsen, Det lille forlag, Frederiksberg.

NiELsen, Morten EBBe JuUl

2005 "Adskillelsen mellem kirke og stat", in: Anna Paldam Folker, Kirsten Hansen \& Sigurd Lauridsen, eds., Bag den politiske retorik - essays $i$ vardikampen, Tiderne Skifter, København, 141-59.

SCHWARTZMAN, MICAH

2005 “The Relevance of Locke's Religious Argument for Toleration”, Political Theory, Vol. 33, No. 5, 678-705.

SPINNER-HALEV, JEFF,

2005 "Hinduism, Christianity, and Liberal Religious Toleration", Political Theory, Vol. 33, No. 1, 28-57.

TAYLOR, CHARLES

1998 "Modes of Secularism", in: Rajeev Bhargava, ed., Secularism and Its Critics, Oxford University Press, Oxford, 31-53.

WALDRON, JEREMY

2002 God, Locke, and Equality. Christian Foundations in Locke's Political Thought, Cambridge University Press, Cambridge.

WEITHMAN, PAUL J.

2002 Religion and the Obligations of Citizenship, Cambridge University Press, Cambridge.

Anders Berg-Sørensen

Adjunkt, ph.d.

Institut for Statskundskab

Københavns Universitet 